\title{
ANALISIS NON PERFORMING FINANCING (NPF) SECARA UMUM DAN SEGMEN MIKRO PADA TIGA BANK SYARIAH NASIONAL DI INDONESIA
}

\author{
NON PERFORMING FINANCING ANALYSIS WITH REGARD TO A GENERAL AND MICRO SEGMENT ON \\ THREE NATIONAL SHARIA BANKS IN INDONESIA
}

\author{
Wulandari Kuswahariani ${ }^{*}$, Hermanto Siregar ${ }^{* *}$, dan Ferry Syarifuddin ${ }^{* * *}$ \\ *) Sekolah Bisnis, IPB University (SB-IPB) \\ Jl. Raya Pajajaran Bogor 16151 \\ ${ }^{* *}$ Departement Ilmu Ekonomi, Fakultas Ekonomi dan Manajemen, IPB University \\ Jl. Agatis Kampus IPB Darmaga, Bogor 16680 \\ ${ }^{* * *}$ Bank Indonesia Institute, Bank Indonesia \\ Jl. M.H. Thamrin, Kota Jakarta Pusat, Daerah Khusus Ibukota Jakarta 10350
}

\begin{abstract}
Non-Performing Financing (NPF) is one of the indicators in evaluating the performance of sharia banks. The high NPF level indicates the low performance of sharia banks that shows many financing problems. The research objective was to identify the factors that influence NPF with regard to general and micro-segment. NPF value influenced by several factors, both internally and externally, such as Financing to Deposit Ratio (FDR), Capital Adequacy Ratio (CAR), Net Operating Margin (NOM), Return On Equity (ROE), inflation, exchange rate, and Gross Domestic Product (GDP). The study used quarterly data from three sharia banks, namely BNI Syariah, BRI Syariah, dan BSM. The methods employed were descriptive analysis and panel data regression. The results showed that FDR, NOM, and ROE were the NPF influencing factors for the general segment. Meanwhile, CAR, NOM, ROA, BOPO, and GDP were the NPF influencing factors for the micro-segment.
\end{abstract}

Keywords: financing, micro segment NPF, NPF, sharia bank

\begin{abstract}
Abstrak: Non Performing Financing (NPF) merupakan salah satu indikator dalam menilai kinerja bank syariah. Tingkat NPF yang tinggi menunjukkan kinerja bank syariah yang rendah karena banyak terjadi pembiayaan bermasalah. Tujuan penelitian ini adalah mengetahui faktor yang memengaruhi NPF baik pada segmen mikro dan NPF secara umum. Nilai NPF dipengaruhi oleh beberapa faktor antara lain baik dari sisi internal dan eksternal seperti Financing to Deposit Ratio (FDR), Capital Adequacy Ratio (CAR), Net Operating Margin (NOM), Return On Equity (ROE), Inflasi, Nilai tukar dan Gross Domestic Product (GDP). Data uang digunakan data triwulan dari 3 bank syariah yaitu BNI Syariah, BRI Syariah dan BSM. Metode yang digunakan dalam penelitian ini yaitu analisis deskriptif dan regresi data panel. Berdasarkan hasil analisis, variabel FDR, NOM dan ROE memiliki pengaruh signfikan negatif terhadap NPF secara umum. Pada NPF segmen mikro, variabel CAR, ROA dan BOPO memiliki pengaruh positif dan signifikan, sedangkan variabel NOM dan GDP memiliki pengaruh negatif dan signifikan.
\end{abstract}

Kata kunci: bank syariah, NPF, NPF segmen mikro, pembiayaan

\footnotetext{
${ }^{1}$ Corresponding author:

Email: wulandari.kuswahariani@gmail.com
} 


\section{PENDAHULUAN}

Pembiayaan merupakan aktivitas penyaluran dana yang dilakukan oleh bank syariah kepada masyarakat yang membutuhkan. Dana yang digunakan untuk pembiayaan merupakan dana yang telah dikumpulkan bank dari masyarakat yang memiliki dana surplus. Secara umum, segmen pembiayaan nasabah perbankan syariah di Indonesia didominasi oleh pembiayaan konsumtif, kemudian diikuti dengan pembiayaan produktif. Rata-rata komposisi pembiayaan sektor ritel konsumtif adalah $40,8 \%$ dari total portofolio perbankan. Sementara itu, presentase rata-rata untuk sektor mikro sebesar 21,66\% dan korporasi 36,5\%.

Sektor kecil dan menengah memiliki peran yang sangat besar di Indonesia, dengan kontribusi terhadap pertumbuhan ekonomi yang cukup signifikan. Namun, sektor kecil dan mikro menghadapi masalah terkait untuk pembiayaan eksternal. Beberapa bank komersial masih enggan untuk membiayai sektor kecil dan mikro dikarenakan sektor ini masih memiliki masalah internal seperti aspek kemampuan manajerial dan kurangnya komitmen dalam hal perjanjian. Hal ini menyebabkan penyaluran pembiayaan pada segmen mikro justru dinilai memiliki tingkat risiko yang tinggi.

Dalam penyaluran pembiayaan secara keseluruhan pun, tidak terlepas dari unsur risiko, salah satunya risiko pembiayaan macet. Risiko pembiayaan macet pada bank umum konvensional ditunjukkan dengan tingan Non Performing Loan (NPL) dan bank umum syariah dicerminkan oleh rasio Non Performing Financing (NPF). Semakin tinggi rasio NPL atau NPF suatu bank maka semakin besar juga tingkat risiko pembiayaan bermasalah yang ditanggung oleh pihak bank. Gambar 1 menunjukkan pertumbuhan tingkat NPL dan NPF tahun 2011 hingga 2017 mengalami turun naik yang cukup fluktuatif.

Tingkat NPF yang tinggi akan berdampak pada pembentukan cadangan kerugian (PPAP) menjadi besar, laba usaha menjadi menurun, pembentukan tambahan modal pun menjadi rendah. Bagi nasabah Dana Pihak Ketiga (DPK) akan terkena dampak perolehan bagi hasildari dananya menjadi rendah, sehingga dapat berpotensi pindah ke bank lain atau ke investasi lain yang lebih menguntungkan

Yulianto dan Solikhah (2016) menyatakan jika rasio NPF suatu bank meningkat, akan terjadi penurunan jumlah simpanan yang bisa dikumpulkan dari nasabah. Keinginan masyarakat untuk menabung atau menaruh dananya di bank syariah akan berkurang karena takut dana yang tersimpan tidak dapat dikembalikan oleh bank atau pun hanya mendapatkan bagi hasil yang kecil.

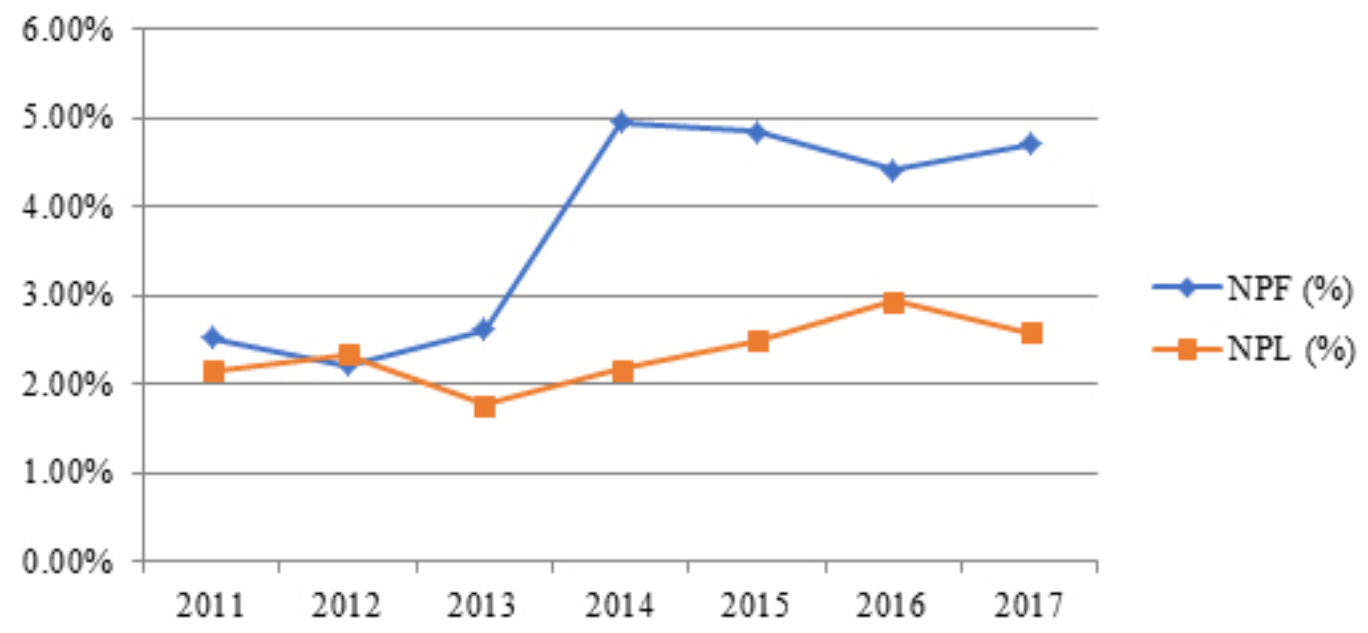

Gambar 1.Perbandingan tingkat NPL Bank Umum Konvensional dan NPF Bank Umum Syariah tahun 2011-2017 
Fenomena risiko pembiayaan pada perbankan dapat dipicu oleh faktor internal dan faktor eksternal. Faktor internal yang memengaruhi NPF, yaitu RR, ROA, CAR dan BOPO (Effendi et al. 2017). Berdasarkan penelitian yang dilakukan oleh Maidalena (2014) dan Asnaini (2014), terdapat pengaruh antara variabel Capital Adequacy Ratio (CAR) terhadap Non Performing Financing (NPF), semakin besar jumlah modal yang dimiliki suatu bank maka akan semakin kecil peluang terjadinya piutang NPF. Selain itu, faktor internal lain yang memengaruhi NPF adalah likuiditas bank dan ukuran bank. Firmansyah (2014) likuiditas bank yang diukur dengan FDR (Finance to Deposit Ratio) menunjukan berpengaruh positif terhadap pembiayaan bermasalah.

Faktor eksternal yang memengaruhi NPF yaitu GDP, inflasi dan nilai tukar. Firdaus (2015) menyatakan bahwa dalam uji F, variabel eksternal (GDP, inflasi dan kurs) mempunyai pengaruh yang lebih kuat dibanding dengan variabel internal dalam memengaruhi NPF. Penelitian yang dilakukan Naibaho dan Rahayu (2018) menyatakan GDP, inflasi, BI rate dan nilai tukar berpengaruh secara bersama-sama terhadap NPF. Perkembangan makro ekonomi seperti pertumbuhan ekonomi, tingkat bunga, nilai tukar, dan inflasi akan mencerminkan stabilitas perekonomian yang dapat memengaruhi kinerja sektor keuangan suatu negara.

Penelitian-penelitian terdahulu lebih banyak membahas mengenai NPF secara umum. Penelitian ini menjadi penting karena masih sedikit yang membahas NPF per segmen, khususnya pada segmen mikro pada bank syariah. Padahal pembiayaan segmen mikro memiliki potensi yang cukup besar untuk dikembangkan pada perbankan syariah.

Dari beberapa permasalah tersebut, maka peneliti tertarik untuk meneliti terkait dengan faktor internal dan faktor eksternal yang memengaruhi NPF pada bank syariah, khususnya bank umum syariah nasional baik secara umum dan pada segmen mikro. Faktor internal yang akan diamati dalam penelitian ini yaitu FDR, CAR, net operating margin dan return to equity. Faktor eksternal yang akan diamati yaitu inflasi dan GDP. Dengan mengetahui faktor-faktor yang memengaruhi meningkatnya NPF secara umum dan segmen mikro diharapkan dapat memitigasi risiko pembiayaan bermasalah yang akan terjadi.
Penelitian ini bertujuan untuk menjelaskan kondisi pembiayaan bermasalah bank syariah baik secara umum dan segmen mikro. Di samping itu, menganalisis faktor-faktor internal dan eksternal yang memengaruhi NPF secara umum dan segmen mikro.

\section{METODE PENELITIAN}

Penelitian menggunakan data dari 3 bank umum syariah yaitu Bank Mandiri Syariah, Bank Rakyat Indonesia Syariah dan Bank Negara Indonesia Syariah. Data yang digunakan dalam penelitian diperoleh dari data triwulan laporan keuangan tiap bank syariah tersebut mulai dari periode 2011 hingga periode 2017. Semua data yang digunakan dalam penelitian diperoleh melalui pengumpulan data sekunder yang tersedia pada masing-masing laporan keuangan bank syariah, Bank Indonesia, dan Otorisasi Jasa Keuangan (OJK).

Dalam penelitian ini digunakan analisis deskriptif dan analisis regresi data panel. Analisis deskriptif didapat dengan melihat hasil minimum, maksimum, rata-rata, maupun standar deviasi dari setiap variabel yang digunakan selama periode penelitian yaitu 2011 hingga 2017. Analisis tersebut digunakan untuk mendeskripsikan variabel - variabel yang memengaruhi terhadap tingkat NPF secara umum dan terhadap NPF pada segmenmikro. Analisis data panel digunakan untuk mengevaluasi faktor-faktor yang dapat memengaruhi tingkat NPF pada bank umum syariah.

Berikut model data panel yang digunakan:

$Y_{i t}=\alpha_{i t}-\beta_{1} X_{1(i t)}-\beta_{2} X_{2(i t)}+\beta_{3} X_{3(i t)}-\beta_{4} X_{4(\text { it })}+\beta_{5} X_{5(i t)}-$ $\beta_{6} X_{6(\text { it })}+\varepsilon_{\text {it }}$

Dengan keterangan: Y (NPF secara umum dan NPF segmen mikro (\%)); $\alpha$ (konstanta); $\beta$ (koefisien regresi dari masing-masing variabel); $\mathrm{X}_{1}$ (Financing to Deposit Ratio (\%)); $\mathrm{X}_{2}$ (CAR (\%)); $\mathrm{X}_{3}($ Net Operating Margin $(\%)) ; \mathrm{X}_{4}$ (return to equity (\%)); $\mathrm{X}_{5}($ Inflasi $(\%)) ; \mathrm{X}_{6}$ (GDP (\%)).

Pengaruh FDR terhadap NPF secara umum dan mikro

Peningkatan penyaluran pembiayaan ditunjukkan dengan rasio FDR yang juga meningkat. Penelitian yang dilakukan oleh Ahmad (2015) dan Budiman et al. (2018) menunjukkan bahwa peningkatan jumlah pembiayaan akan menurunkan rasio NPF dan sesuai dengan perhitungan rasio NPF. Poetry dan Sanrego 
(2011), menyatakan kualitas FDR yang baik berdampak pada ekspensi pembiayaan yang memberikan kontribusi yang baik bagi peningkatan perbankan sehingga NPF akan menurun. Tetapi, ketika FDR yang tinggi tidak didukung dengan loan review dan pengawasan yang baik, maka dapat mengakibatkan meningkatnya pembiayaan yang bermasalah atau macet. H1 : FDR berpengaruh negatif terhadap NPF secara umum dan mikro.

Pengaruh CAR terhadap NPF secara umum dan mikro

Capital Adequacy Ratio (CAR) merupakan kecukupan modal, menunjukkan kemampuan bank dalam mempertahankan modal yang mencukupi dan kemampuan manajemen bank dalam mengidentifikasikan, mengukur, mengawasi, dan mengontrol resiko yang timbul dan dapat berpengaruh terhadap besarnya modal bank.

Hasil penelitian Asnaini (2014) menunjukan CAR memberikan pengaruh negatif dan signifikan terhadap NPF pada Bank Umum Syariah di Indonesia. Semakin besar jumlah modal yang dimiliki suatu bank maka akan semakin kecil peluang terjadinya pembiayaan bermasalah. Hasil penelitian sebelumnya yang dilakukan oleh Rahman dan Shahimi (2010), Misman (2012), Makri et al. (2014) menyatakan bahwa rasio CAR berpengaruh negatif dan signifikan terhadap NPF secara umum dan mikro. H2 : CAR berpengaruh negatif terhadap NPF.

Pengaruh NOM terhadap NPF secara umum dan mikro

Net Operating Margin (NOM) menunjukkan kemampuan bank dalam menghasilkan laba dari aktiva produktifnya. Semakin besar rasio NOM maka semakin besar laba yang dihasilkan. Baik pada pembiayaan secara umum ataupun mikro, rasio NOM yang meningkat diikuti juga dengan peningkatan nilai pembiayaan bermasalah, hasil penelitian Shingjergji (2013), Santosa et al. (2014), dan Lusian (2015). Menurut Lusian (2015), tingkat margin keuntungan yang besar (diatas rata-rata) pada bank pembiayaan rakyat syariah memiliki jumlah nasabah yang paling besar pembiayaan bermasalahnya. Informasi tingkat rata-rata margin pembiayaan sangat penting untuk dijadikan acuan dalam penawaran pembiayaan kepada nasabah. H3 : NOM berpengaruh positif terhadap NPF secara umum dan mikro.
Pengaruh ROE terhadap NPF secara umum dan mikro

Rasio ROE memiliki nilai negatif dan signifikan terhadap NPF, hal ini berdasarkan dari penelitian yang dilakukan oleh Shingjergji (2013), dan Makri et al. (2014). Wood dan Skinner (2018) juga menyatakan bahwa semakin baik ROE semakin efektif manajemen dalam memanfaatkan modal pemegang saham, sehingga berpengaruh terhadap pembiayaan bermasalah yang menurun. H4 : ROE berpengaruh negatif terhadap NPF.

Pengaruh inflasi terhadap NPF secara umum dan mikro

Inflasi merupakan salah satu indikator variabel makro. Inflasi akan memengaruhi kegiatan ekonomi baik secara makro maupun mikro termasuk kegiatan investasi. Inflasi juga menyebabkan penurunan daya beli masyarakat yang berakibat pada penurunan penjualan. Penurunan penjualan yang terjadi dapat menurunkan return perusahaan. Penurunan return yang terjadi akan memengaruhi kemampuan perusahaan dalam membayar angsuran kredit. Hasil penelitian Yanti (2012), Badar et al. (2013) serta Radivojevic dan Jovovic (2017) menyatakan inflasi memiliki pengaruh signfikan positif terhadap nilai kredit atau pembiayaan bermasalah. H5 : Inflasi berpengaruh positif terhadap NPF.

Pengaruh GDP terhadap NPF secara umum dan segmen mikro

Firdaus (2015) menyatakan peningkatan konsumsi swasta yang diiringi dengan penurunan tingkat investasi dan penurunan PDB riil dapat diartikan sebagai penurunan kemampuan untuk memproduksi barang dan jasa dalam perekonomian. Hal tersebut pada gilirannya akan memengaruhi kemampuan perusahaan untuk memperoleh hasil usaha yang digunakan untuk membayar kembali pembiayaan yang diterima dari perbankan. Peningkatan konsumsi yang diiringi dengan menurunnya investasi dan tingkat GDP riil maka mengindikasikan penurunan dalam memproduksi barang dan jasa. Hal tersebut akan memengaruhi tingkat hasil usaha yang diperoleh perusahaan yang merupakan sumber dana dalam pembayaran kredit dari lembaga perbankan. 
Penelitian terkait pembiayaan bermasalah pada bank perkreditan rakyat syariah yang dilakukan oleh Firmansyah (2014), menyatakan GDP berpengaruh negatif terhadap pembiayaan bermasalah pada BPRS. Artinya, jika perekonomian sedang naik maka pembiayaan bermasalah pada BPRS akan berkurang sehingga GDP menjadi sinyal positif bagi BPRS. H6: Peningkatan GDP berpengaruh negatif terhadap NPF.

Penyaluran kredit atau pembiayaan merupakan aktivitas bank yang utama dalam menghasilkan keuntungan, tetapi risiko yang terbesar juga berasal dari risiko kredit. Risiko kredit atau pembiayaan pada bank syariah ditunjukkan dengan tingginya tingkat pembiayaan bermasalah atau disebut juga dengan NPF. Nilai NPF yang tinggi dan melebihi batas dapat mengganggu profitabilitas bank syariah. Dalam hal ini, maka diperlukan analisis terkait faktor- faktor yang memengaruhi tingginya nilai NPF.
Pada penelitian ini akan diambil data NPF dari 3 bank syariah nasional, yaitu BRI Syariah, BNI Syariah dan Mandiri Syariah. Berdasarkan Gambar 2, nilai NPF diamati berdasarkan 2 segmentasi bisnis, yaitu NPF secara umum dan NPF dan segmen mikro. Terdapat dua faktor yang akan dianalisis dalam penelitian ini yaitu faktor yaitu internal dan eksternal. Variabel pada faktor internal meliputi FDR, CAR, NOM dan ROE. Variabel eksternal yang akan dianalisis yaitu inflasi, dan GDP.

Teknik pengolahan data yang dilakukan menggunakan analisis deskriptif dan analisis regresi data panel. Analisis deskriptif bertujuan untuk menjelaskan kondisi pembiayaan bermasalah dan juga menjelaskan secara umum kondisi variabel-variabel yang memengaruhi tingkat NPF. Analisis regresi data panel dilakukan untuk menganalisis variabel-variabel yang memengaruhi NPF baik secara umum maupun segmen mikro. Hasil analisis tersebut kemudian dirangkum untuk dijadikan bahan pertimbangan dalam implikasi manajerial yang nantinya akan dimanfaatkan untuk memitigasi risiko pembiayaan bermasalah yang akan terjadi.

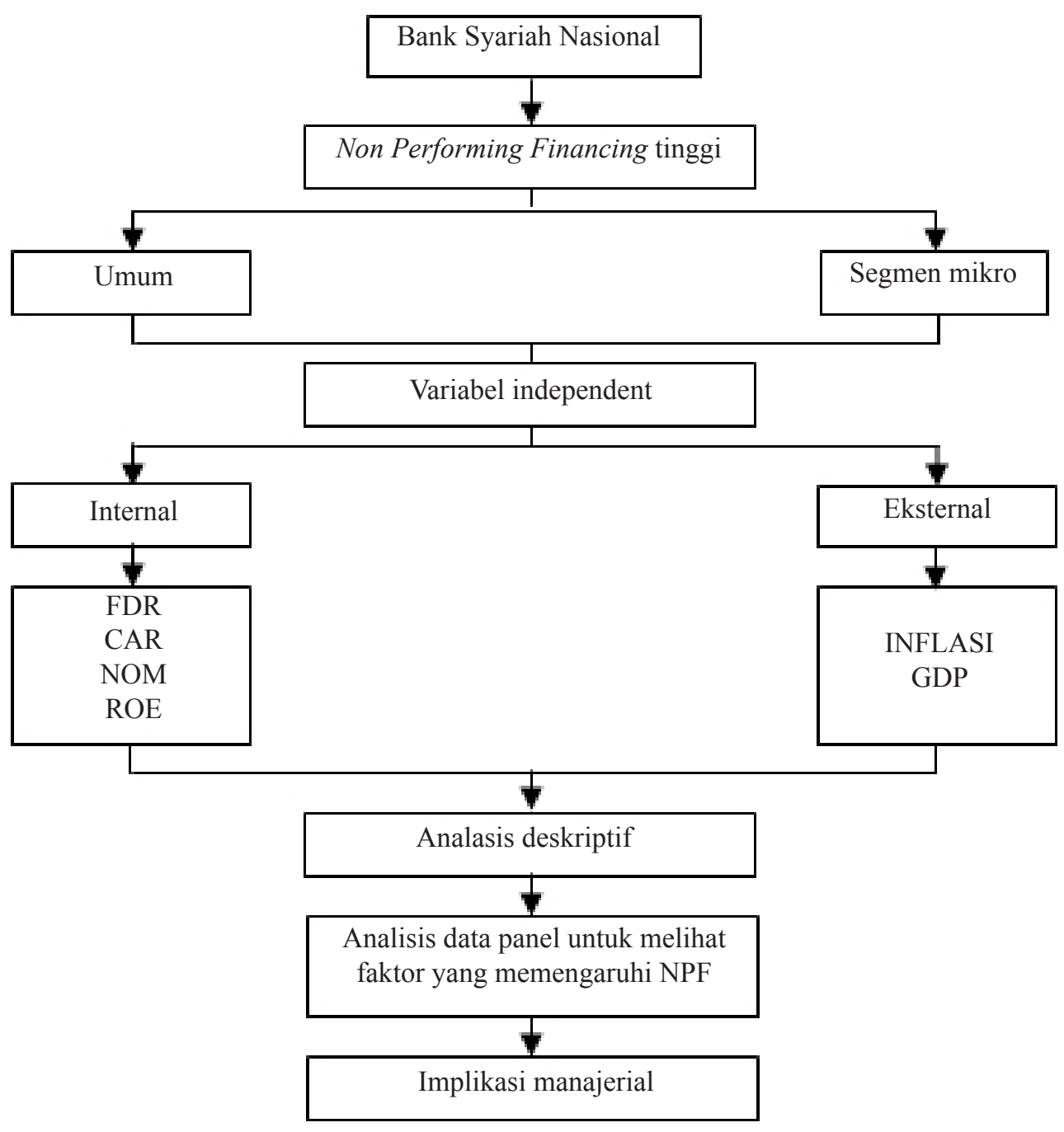

Gambar 2. Kerangka pemikiran penelitian 


\section{HASIL}

Hasil deskriptif statistik (Tabel 1), akan dibahas mengenai karakteristik dari setiap variabel yang digunakan dalam penelitian. Analisis desriptif variabel rasio keuangan dan makro ekonomi terhadap NPF bank syariah selama periode tahun 2011 sampai 2017 meliputi mean, nilai maximum, nilai minimum, dan standar deviasi. Dengan variabel yang meliputi NPF baik secara umum dan mikro (NPFM), FDR, CAR, NOM, ROE, inflasi, dan GDP.

Jika dilihat dari rasio CAR ketiga bank yang diuji, mengindikasi bahwa CAR ketiga bank ini cukup memadai dan berada di atas besaran CAR yang ditetapkan oleh BI sebesar 8\%. Rasio CAR ini menunjukkan semakin besar nilai CAR maka semakin besar pula cadangan penyediaan modal yang digunakan untuk menutupi risiko kerugian. Tingginya CAR mengindikasi adanya sumber daya finansial (modal) yang idle. Pulihnya perekonomian dan perbankan secara berangsur-angsur telah mendorong optimalisasi kegunaan sumber daya finansial (modal) melalui penyaluran kredit. Penyaluran kredit atau pembiayaan mengalami peningkatan seiring dengan penurunan CAR.

Pada variabel, NOM nilai mean sebesar 7,33\%. Nilai maksimum data NOM, yaitu $11,03 \%$ yang dimiliki oleh BNI Syariah dan nilai minimum sebesar 5.57\% pada BRI Syariah. Standar deviasi pada variabel NOM lebih kecil dari nilai meansehingga data variabel NOM memiliki penyebaran data yang baik. Nilai NOM menunjukan kemampuan manajemen bank dalam mengelola aktiva produktifnya untuk menghasilkan pendapatan bagi hasil. NOM yang baik memiliki nilai diatas 3\% sehingga dapat dikatakan nilai NOM pada 3 bank syariah yang diuji baik.

Nilai GDP yang rendah pada tahun 2015 menunjukkan adanya perlambatan pertumbuhan ekonomi. Menurut laporan perekonomian Indonesia tahun 2015, pertumbuhan ekonomi negara-negara emerging marketsyang merupakan sumber utama pertumbuhan ekonomi global, cenderung melambat di tahun 2015. Salah satu motor ekonomi dunia yang juga mitra dagang utama Indonesia, yaitu Tiongkok, terus menunjukan perlambatan ekonomi. Melambatnya pertumbuhan ekonomi global berpengaruh terhadap penurunan harga komoditas dan penurunan kinerja ekspor Indonesia.

Gambaran NPF secara umum dan segmentasi mikro pada ketiga bank syariah nasional yaitu bank BNI Syariah, BRI Syariah dan BSM digambarkan pada Gambar 3. Dari ketiga bank syariah tersebut, nilai NPF tertinggi yaitu Bank Syariah Mandiri pada tahun 2015 quarter 3, dengan nilai NPF sebesar 6,89\%. Nilai NPF terendah, yaitu BNI Syariah sebesar 1,86\%. Secara umum, rata-rata NPF ketiga bank syariah ini masih berada dalam batas nilai NPF yang ditetapkan oleh BI, yaitu 5\%. rata-rata nilai NPF secara umum, yaitu 3,82\%. Sedangkan berbeda dengan nilai NPF pada segmentasi pembiayaan mikro yang cukup tinggi, Nilai NPF segmentasi mikro tertinggi yaitu pada Bank Syariah Mandiri di 12,77\% dan NPF segmentasi mikro terendah yaitu BRI Syariah mencapai $1,59 \%$. Nilai rata-rata NPF segmentasi mikro diatas batas NPF yang ditetapkan $\mathrm{BI}$, rata-rata NPF pada segmen mikro mencapai $5,45 \%$.

Tabel 1. Statistik deskriptif variabel NPF Bank Umum Syariah

\begin{tabular}{lccccc}
\hline Variabel & $\mathrm{N}$ & Mean & Maximum & Minimum & Std Dev \\
\hline NPF & 84 & 3,82 & 6,89 & 1,86 & 1,39 \\
NPFM & 84 & 5,45 & 12,77 & 1,59 & 2,66 \\
FDR & 84 & 88,43 & 105,61 & 71,87 & 7,97 \\
CAR & 84 & 15,50 & 25,91 & 11,03 & 2,97 \\
NOM & 84 & 7,33 & 11,03 & 5,57 & 1,16 \\
ROE & 84 & 16,93 & 74,43 & 0,24 & 20,36 \\
Inflasi & 84 & 5,25 & 8,6 & 3,02 & 1,61 \\
GDP & 84 & 5,48 & 6,52 & 4,66 & 0,64 \\
\hline
\end{tabular}


Baik pada pembiayaan bermasalah secara umum dan pada segmentasi mikro, Bank Syariah Mandiri memiliki nilai pembiayaan bermasalah yang tinggi. Pembiayaan bermasalah mulai meningkat mulai dari 2104 hingga 2015. Penyebab terjadinya NPF dan NPF segmentasi mikro yang meningkat, disebabkan karena pertumbuhan ekonomi yang melambat. Pertumbuhan ekonomi yang rendah di 2014 dan 2015, dibandingkan dengan tahun sebelumnya, membuat hampir semua bank syariah melakukan revisi target pembiayaan.

\section{Faktor-faktor Internal dan Eksternal yang Memengaruhi NPF Secara Umum dan Mikro}

Setelah dilakukan penanganan terhadap asumsiasumsi klasik, maka diperoleh model terbaik dengan Fixed Effect Model (FEM). Tabel 2. menunjukan hasil pengujian data panel menggunakan pendekatan
FEM. Hasil estimasi model regresi, variabel yang memengaruhi NPF secara umum, yaitu FDR, NOM, dan ROE. Pada NPF secara mikro yang memengaruhi yaitu CAR, NOM dan GDP.

\section{Pengaruh FDR terhadap NPF}

Kegiatan utama bank sebagai sumber pendapatan yaitu dengan menyalurkan dana yang sudah dihimpun ke dalam bentuk pembiayaan. Pengukuran jumlah dana pihak ketiga yang disalurkan dalam bentuk pembiayaan tersebut diukur dengan menggunakan dengan FDR. Dalam pembiayaan bermasalah secara umum variabel FDR memiliki nilai signifikasi sebesar $(0,00)$ dengan koefisien negatif sebesar (0,076). Sedangkan pada pembiayaan bermasalah segmentasi mikro, variabel FDR memiliki nilai probabilitas sebesar $(0,108)$ dengan koefisien yang juga negatif sebesar $(0,038)$.

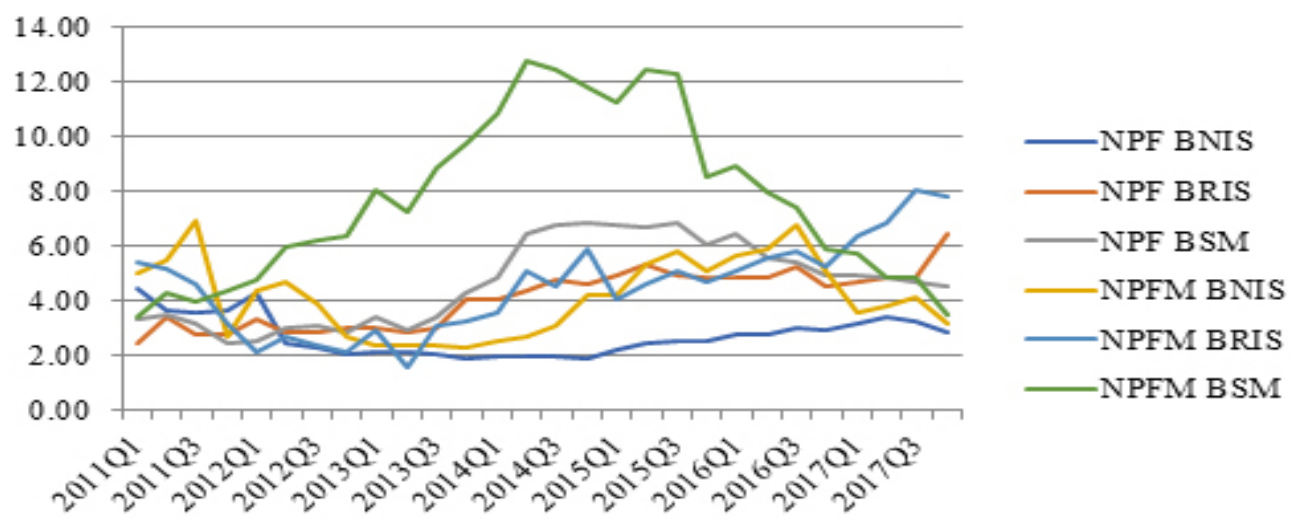

Gambar 3. Grafik NPF segmen mikro dan secara umum pada 3 Bank Syariah

Tabel 2. Hasil estimasi model regresi data panel

\begin{tabular}{lcccc}
\hline \multirow{2}{*}{ Variabel } & \multicolumn{2}{c}{ NPF secara umum } & \multicolumn{2}{c}{ NPF segmen mikro } \\
\cline { 2 - 5 } & Koefisien & Probability & Koefisien & Probability \\
\hline FDR & $-0,076^{* *}$ & 0,000 & $-0,038$ & 0,182 \\
CAR & $-0,038$ & 0,197 & $0,238^{* *}$ & 0,002 \\
NOM & $-0,486^{* *}$ & 0,000 & $-0,516^{*}$ & 0,026 \\
ROE & $-0,046^{* *}$ & 0,000 & 0,012 & 0,587 \\
INFLASI & 0,059 & 0,290 & 0,131 & 0,352 \\
GDP & 0,003 & 0,977 & $-0,812^{*}$ & 0,019 \\
C & 15,503 & 0,000 & $-13,279$ & 0,108 \\
\hline R-squared & & 0,857 & & 0,672 \\
Prob (F-Stat) & 0,000 & & 0,000 \\
\hline Ketrangan $: *$ & & &
\end{tabular}

Keterangan : * signifikasi pada $\alpha \leq 0,05$ dan ** pada $\alpha \leq 0,01$ 
Hasil penelitian ini sejalan dengan hipotesis sebelumnya yang menyatakan bahwa FDR bernilai negatif terhadap NPF. Penelitian ini sejalan dengan penelitian yang dilakukan oleh Ahmad (2015) dan Budiman et al. (2018) menunjukkan bahwa peningkatan jumlah pembiayaan akan menurunkan rasio NPF dan sesuai dengan perhitungan rasio NPF. Hal ini menunjukkan bahwa pada pembiayaan secara umum, peningkatan penyaluran pembiayaan akan memengaruhi penurunan nilai pembiayaan bermasalah. Namun, pada pembiayaan segmentasi mikro, penyaluran pembiayaan tidak memengaruhi nilai pembiayaan bermasalah.

Pada penelitian Poetry dan Sanrego (2011), model NPL bank konvensional dan NPF bank syariah merespon negatif guncangan FDR. Bank syariah memiliki kualitas penyaluran pembiayaan yang baik dengan prinsip kehati-hatian sehingga ekspansi pembiayaan memberikan kontribusi yang baik bagi peningkatan laba perbankan. Penelitian yang dilakukan oleh Vanni dan Rokhman (2017) juga menyatakan bahwa variabel FDR memiliki pengaruh negatif dan signifikan terhadap NPF.

\section{Pengaruh CAR terhadap NPF}

Variabel CAR memiliki kontribusi terhadap risiko kredit dimana ketika pertumbuhan kredit meningkat maka rasio CAR akan menurun. Pada pembiayaan secara umum, variabel CAR memiliki efek negatif tapi tidak berpengaruh signifikan terhadap tingkat NPF secara umum. Penelitian ini sejalan dengan yang dilakukan oleh Budiman et al. (2018), yang menujukkan CAR pada model 1 tidak berpengaruh signifikan terhadap NPF. Tetapi pada model 2 memiliki pengaruh negatif. Hal ini dapat disebabkan bank yang tidak memiliki modal yang banyak sementara harus tetap memberikan return kepada nasabah DPK, sehingga cenderng menurunkan standar dalam penyaluran pembiayaan yang dapat berpotensi meningkatkan NPF.

Pada pembiayaan segmen mikro variabel CAR terhadap NPF memiliki nilai koefisien sebesar $(0,238)$ dengan probabilitas $(0,00)$. Hasil penelitian menunjukkan variabel CAR memiliki pengaruh positif dan signifikan terhadap nilai NPF pada segmentasi mikro. Hasil ini tidak sejalan dengan penelitian Rahman dan Shahimi (2010), Misman (2012), Makri et al. (2014) dan berbeda dari hipotesis sebelumnya yang menunjukan bahwa variabel CAR berpengaruh negatif terhadap nilai kredit macet.
Farika (2018), guncangan CAR diberikan respon negatif oleh risiko kredit. Guncangan tersebut pada awal periode direspon positif, tetapi pada periode pengujian keempat CAR mulai direspon negatif. Risiko pembiayaan memberikan respon yang berbeda, yakni respon positif terhadap guncangan CAR. Penelitian Poetry dan Sanrego (2011) juga menyatakan bahwa respon CAR pada kredit macet bank konvensional dengan pembiayaan bermasalah bank syariah berbeda. Guncangan variabel CAR direspon negatif oleh NPL bank konvensional, sedangkan respon NPF Bank Syariah terhadap CAR justru positif.

Penelitian yang dilakukan oleh Jusmansyah dan Sriyanto (2013) dan Riyadi et al. (2015) memperkuat hasil penelitian ini. Pada NPF mikro, rasio kecukupan modal yang diproksikan oleh CAR memiliki pengaruh positif dan signifikan terhadap NPF. Semakin tinggi rasio kecukupan modal, maka akan semakin meningkatkan NPF pada segmen mikro, begitu pun sebaliknya. Pengendalian kredit macet dapat dimulai dari pengendalian kecukupan modal. Apabila bank syariah ingin menurunkan kredit macet dapat dilakukan dengan menekan atau memantau rasio kecukupan modalnya.

Pengaruh NOM terhadap NPF secara umum dan segmen mikro

Variabel NOM memiliki koefisien pengaruh terhadap NPF secara umum sebesar $(0,486)$ dengan nilai probabilitas sebesar $(0,00)$. Hasil menunjukkan variabel net operating margin memiliki pengaruh negatif dan signifikan terhadap NPF. Hasil yang sama juga pada NPF segmentasi mikro, variabel NOM berpengaruh negatif signifikan terhadap NPF mikro dengan nilai koefisien sebesar $(0,516)$. Hasil dari penelitian ini, tidak sejalan dengan penelitian Shingjergji (2013) dan Lusian (2015) yang menyatakan nilai net operating marginmemiliki pengaruh negatif terhadap pembiayaan bermasalah.

Hasil penelitian menunjukkan bahwa nilai NOM yang tinggi akan menurunkan nilai NPF. Hal ini sejalan dengan penelitian yang dilakukan Nasution (2017) dan Effendi et al. (2017) yang menyatakan nilai NOM yang tinggi akan meningkatkan profitabilitas bank sehingga bank akan dapat mengelola risiko dengan baik yang membuat nilai NPF tidak meningkat. 
Return to Equity (ROE) merupakan rasio profitabilitas yang penting untuk menggambarkan tingkat kesehatan bank. ROE menggambarkan kemampuan bank dalam menghasilkan keuntungan dari setiap rupiah modal ekuitasnya dan saham yang dimiliki oleh investor. Variabel ROE memiliki pengaruh negatif dan signifikan terhadap nilai NPF secara umum, dengan nilai koefisien sebesar $(0,046)$ dan probabilitas $(0,00)$. Sedangkan pada pembiayaan segmentasi mikro, variabel ROE tidak berpengaruh terhadap NPF.

Hasil penelitian ini juga sejalan dengan hasil penelitian Shingjergji (2013), yang menyatakan bahwa peningkatan ROE akan menentukan pengurangan rasio NPL dan begitu juga sebaliknya. Pada penelitian Wood dan Skinner (2018), menyatakan dampak negatif dan signifikan dari ROE pada tingkat kredit bermasalah menunjukkan adanya pengelolaan dana yang baik diinvestasikan oleh pemegang saham (shareholders) di bank komersial di Barbados. Pengelolaan managemen yang buruk dalam pengelolaan dana, akan menyebabkan meningkatnya risiko pembiayaan dan lemahnya keuangan.

\section{Pengaruh Inflasi terhadap NPF}

Berdasarkan hasil pengujian data panel, inflasi memiliki efek positif tetapi tidak memiliki pengaruh terhadap nilai NPF baik secara umum atau pada NPF segmentasi mikro. Hal ini ditunjukan dengan nilai koefisien inflasi sebesar $(0,059)$ pada NPF dan $(0,131)$ pada NPF segmentasi mikro. Nilai probabilitas inflasi sebesar $(0,290)$ pada NPF dan $(0,352)$ pada NPF segmentasi mikro.

Hasil penelitian ini sejalan dengan hasil penelitian yang dilakukan Popita (2015), Asnaini (2014), Firdaus (2015) dan Ntow dan Alu (2016), yang menyatakan inflasi tidak memiliki pengaruh terhadap NPF. Hal ini karena pada pembiayaan syariah, inflasi tidak memengaruhi dalam pembayaran cicilan. Pembayaran kewajiban nasabah pada pembiayaan di bank syariah akan tetap walaupun terjadi inflasi. Pembayaran cicilan pada pembiayaan nasabah ini akan tetap sesuai dengan akad pembiayaan di awal. Perubahan laju inflasi yang meningkat juga tidak langsung menyurutkan keinginan masyarakat untuk mengikuti perkembangan kebutuhan atau mengurangi konsumsi, maka dampak risiko pembiayaan masih dapat terkendali.
Pada pembiayaan secara umum, pengaruh GDP terhadap NPF menunjukkan hasil positif tetapi tidak signifikan terhadap pembiayaan bermasalah secara umum, dengan nilai probabilitas sebesar $(0,979)$. Hasil terkait pengaruh GDP terhadap NPF ini sama dengan penelitian Asnaini (2014) yang menyatakan bahwa GDP tidak berpengaruh terhadap NPF Bank Umum Syariah. Hal ini sesuai dengan hasil penelitian yang dilakukan oleh Popita (2013) dan Mutamimah dan Chasanah (2012) yang menyatakan bahwa GDP berpengaruh positif tetapi tidak signifikan terhadap NPF bank umum syariah.

Kondisi pertumbuhan ekonomi yang meningkat menandakan pendapatan masyarakat juga ikut meningkat. Namun, pada umumnya peningkatan pendapatan juga meningkatkan konsumsi masyarakat. Kecenderungan masyarakat yang konsumtif, akan mengalokasikan pendapatannya untuk konsumsi daripada untuk membayarkan kewajiban pembiayaan ke perbankan (Mutamimah dan Chasanah, 2012).

Pada pembiayaan bermasalah segmentasi mikro, hasil menunjukkan variabel GDP memiliki nilai koefisien sebesar $(0,812)$ dan nilai probabilitas sebesar $(0,019)$. Wibowo dan Saputra (2017) menunjukkan adanya hubungan antara GDP dengan NPF, dalam penelitian tersebut menunjukkan peningkatan GDP akan menurunkan tingkatNPF pada bank syariah. Penelitian ini juga sejalan dengan penelitian Firmansyah (2014), GDP berpengaruh negatif terhadap pembiayaan bermasalah pada BPRS. GDP menunjukkan indikator majunya perekonomian masyarakat. GDP yang meningkat artinya masyarakat (nasabah) semakin mampu dalam melunasi kewajibannya. Sebaliknya, GDP yang menurun maka semakin banyak juga masyarakat yang kesulitan dalam melakukan pembayaran kewajiban.

\section{Implikasi Manajerial}

Kondisi NPF yang belum terselesaikan di tahun sebelumnya, jika tidak segera ditangani maka akan terus terakumulasi dalam pembukuan sehingga rasio NPF akan terus meningkat. Agar rasio NPF tidak semakin meningkat, sebelum pembiayaan tersebut turun statusnya menjadi pembiayaan bermasalah, bank sebaiknya melakukan segera tindakan penyelamatan pembiayaan bermasalah dengan rescheduling, reconditioning, dan juga restrukturisasi pembiayaan. 
Dari hasil penelitian dan temuan empiris terdahulu NOM menjadi variabel yang memengaruhi pembiayaan bermasalah secara umum dan ROA memengaruhi pembiayaan bermasalah pada segmen mikro, antara lain ditemukan oleh Shingjergji (2013), Santosa et al. (2014), Lusian (2015), Aini (2013), Jusmansyah dan Sriyanto (2013) serta Havidz dan Setiawan (2015). Agar dapat memitigasi terjadinya pembiayaan bermasalah masing-masing bank harus menetapkan batas nilai NOM yang sesuai dan untuk dapat tetap meningkatkan rasio ROA yang merupakan indikasi profitabilitas, dan juga dalam mengurangi tingginya NPF, Bank Syariah harus tetap menerapkan prinsip kehati-hatian dan selektif dalam pemberian pembiayaan.

\section{KESIMPULAN DAN SARAN}

\section{Kesimpulan}

Berdasarkan hasil analisis perbandingan NPF bank syariah nasional secara umum dan segmentasi mikro pada tiga bank syariah periode tahun 2011 sampai 2017, maka dapat disimpulkan bahwa NPF cenderung mengalami peningkatan, dengan rata-rata NPF secara umum sebesar $3.82 \%$. Sedangkan rata-rata NPF pada segmentasi mikro melebihi batas nilai NPF yang telah ditetapkan dengan nilai 5.45\%.Nilai NPF pada pembiayaan segmentasi mikro lebih tinggi dibandingkan NPF secara umum. Sehingga bank syariah harus lebih memperketat ketentuan dalam penyaluran pembiayaan khususnya pada pembiayaan segmentasi mikro.

Faktor yang berpengaruh signifikan terhadap NPF secara umum yaitu financing to deposit ratio (FDR), net operating margin (NOM) dan return to equity (ROE). Ketiga variabel tersebut memiliki pengaruh negatif terhadap NPF. Kenaikan nilai FDR, NOM dan ROE akan menyebabkan pembiayaan bermasalah menurun. Pada segmentasi mikro, yang berpengaruh signifikan terhadap NPF yaitu CAR, NOM, dan GDP. Variabel CAR memiliki pengaruh positif dan signifikan terhadap NPF segmen mikro. Peningkatan nilai CAR akan menyebabkan pembiayaan bermasalah pada segmentasi mikro semakin bertambah. Sedangkan variabel NOM dan GDP memiliki pengaruh negatif dan signifikan. Sehingga kenaikan nilai NOM dan GDP akan menurunkan persentase pembiayaan bermasalah pada segmen mikro.

\section{Saran}

Penelitian selanjutnya dapat menambahkan segmentasi pembiayaan yang lainnya untuk analisa lebih mendalam terkait pembiayaan bermasalah. Segmentasi yang dapat ditambahkan seperti koorporasi, ritel, dan konsumer. Selain itu, penelitian selanjutnya juga dapat membandingkan NPF berdasarkan bank umum kelompok usaha (BUKU).

\section{DAFTAR PUSTAKA}

Ahmad NH. 2015. Impaired financing determinants of Islamic banks in Malaysia. Information Management and Business Review 7(3):17-25. https://doi.org/10.22610/imbr.v7i3.1149.

Asnaini SW. 2014. Faktor-faktor yang memengaruhi non performing financing (NPF) pada bank umum syariah di indonesia. Jurnal Tekun 5(2): 264-284.https://doi.org/10.26740/jaj.v5n2. p205-225.

Badar M, Javid AY, Zulfiquar S. 2013. Impact of macro economic forces on Nonperforming loans an empical study of commercial banks in Pakistan. Elixir International Journal 56(A): 1380713814.

Budiman R, Achsani NA, Ismail R. 2018. Risiko pembiayaan dan determinannya pada perbankan syariah di Indonesia. Jurnal Aplikasi Manajemen dan Bisnis 4(1): 151-159. https:// doi.org/10.17358/jabm.4.1.151.

Effendi J, Thiarany U, Nursyamsiah T. 2017. Factors influencing non-performing financing (NPF) at sharia banking. Walisongo: Jurnal Penelitian Sosial dan Keagamaan 25(1): 109-138.https:// doi.org/10.21580/ws.25.1.1540.

Farika M. 2018. Analisis pengaruh variabel makro dan mikro terhadap risiko kredit/pembiayaan perbankan di Indonesia. [tesis]. Bogor:Sekolah Bisnis Institut Pertanian Bogor.

Firdaus RN. 2015. Pengaruh faktorinternal dan eksternal yang memengaruhi pembiayaan bermasalah pada bank umum syariah di Indonesia. El Dinar 3(1): 82-108. https://doi.org/10.18860/ed.v3i1.3339.

Firmansyah I. 2014. Determinant of non performing loan: the case of islamic bank in Indonesia. Buletin Ekonomi Moneter dan Perbankan 17(2): 233-247. https://doi.org/10.21098/bemp. v17i2.51. 
Havidz SAH, Setiawan C. 2015. Bank efficiency and Non-Performing Financing in Indonesian Islamic Bank. Asian Journal of Economic Modelling 3(3): 61-79.https://doi.org/10.18488/ journal.8/2015.3.3/8.3.61.79.

Jusmansyah M, Sriyanto A. 2013. Analisis pengaruh CAR, BOPO, dan ROA terhadap non performing loan. Jurnal Ilmiah Universitas Budi Luhur 2(1): 46-63.

Lusian S. 2015. Analisis faktor-faktor penyebab pembiayaan bermasalah di bank pembiayaan rakyat syariah XYZ periode 2009-2013. [tesis]. Bogor: Institut Pertanian Bogor.

Maidalena. 2014. Analisis faktor non performing financing (npf) pada industri perbankan syariah. Jurnal Ekonomi dan Bisnis Islam1(1): 126-137.

Makri V, Tsagkanos A, Bellas A. 2014. Determinants of non-performing loans: the case of Eurozone. Panoeconomicus 61(2): 193-206. https://doi. org/10.2298/PAN1402193M.

Misman FN. 2012. Financing structure, bank specific variables and credit risk: Malaysian Islamic banks. Journal of Business and Policy Research.7(1):102-114.

Mutamimah, Chasanah SNZ. 2012. Analisis eksternal dan internal dalam menentukan non performing financing bank umum syariah di Indonesia. Jurnal Bisnis dan Ekonomi (JBE) 19 (1): 4964.

Naibaho K, Rahayu SM. 2018. Pengaruh GDP, inflasi, BI Rate, nilai tukar terhadap Non Performing Loan Bank Umum Konvensional di Indonesia. Jurnal Administrasi Bisnis (JAB) 62 (2): 87-96.

Nasution IK. 2017. Pengaruh FDR, CAR, NPF dan BOPO terhadap Net Operating Margin (NOM) bank pembiayaan rakyat syariah di Indonesia [tesis]. Jakarta: UIN.

Ntow ELM, Alu GAA. 2016. Nonperforming loans and bank profitability : evidence form an emerging market. African Journal of Economic and Management Studies 7(4): 462-481.https://doi. org/10.1108/AJEMS-07-2015-0088.

Poetry ZD, Sanrego YD. 2011. Pengaruh variabel makro dan mikro terhadap NPL perbankan konvensional dan NPF perbankan syariah. Islamic Finance \& Business Review 6(2): 79-104.

Popita MSA. 2013. Analisis penyebab terjadinya non performing financing pada bank umum syariah di Indonesia. Accounting Analysis Journal 2(4): 404-412.

Radivojevic N, Jovovic J. 2017. Examining of determinants of non-performing loans. Prague Economic Papers 26(3): 300-316.https://doi. org/10.18267/j.pep.615.

Rahman AA, Shahimi S. 2010. Credit risk and financing structure of Malaysian Islamic banks. Journal of Economic Cooperation and Development 31(3):83-105.

Riyadi S, Iqbal M, Lauren N. 2015. Strategi pengelolaan non performing loan bank umum yang go public. Jurnal Dinamika Manajemen 6(1): 84-96. https://doi.org/10.15294/jdm.v6i1.4299.

Santosa SB, Sudarto, Sunarko B. 2014. Analisis pengaruh LDR, BOPO, Size, LAR, dan NIM terhadap NPL pada BPR konvensional di wilayah Jawa Tengah. Jurnal \& Proceeding Fakultas Ekonomi dan Bisnis UNSOED 4(1): 687-699.

Shingjergji A. 2013. The impact of bank specific variables on the non performing loans ratio in the Albanian banking system. Research Journal of Finance and Accounting 4(7): 148-153.

Vanni KM, Rokhman W. 2017. Analisis faktor-faktor yang memengaruhi Non Performing Financing pada Perbankan Syariah di Indonesia tahun 2011-2016. EQILIBRIUM: Jurnal Ekonomi Syariah 5 (2): 306-319.https://doi.org/10.21043/ equilibrium.v5i2.2776.

Wibowo SA, Saputra W. 2017. Pengaruh variabel makro dan mikro ekonomi terhadap pembiayaan bermasalah pada bank syariah. Jurnal Ilmiah Akuntansi 2(1): 96 -112. https://doi. org/10.23887/jia.v2i1.10040.

Wood A, Skinner A. 2018. Determinants of nonperforming loans: evidence from commercial banks in Barbados. The Business and Management Review 9(3): 44-64.

Yanti MISM. 2012. Evaluasi faktor determinan risiko kredit dalam rangka implementasi program BPD regional champion pada bank pembangunan daerah seluruh Indonesia [tesis]. Jakarta: Universitas Indonesia.

Yulianto A, Solikhah B. 2016. The Internal Factors of Indonesian Sharian Banking to Predict The Mudharabah Deposits. Review of Integrative Business \& Economic Research 5(1): 210-218 